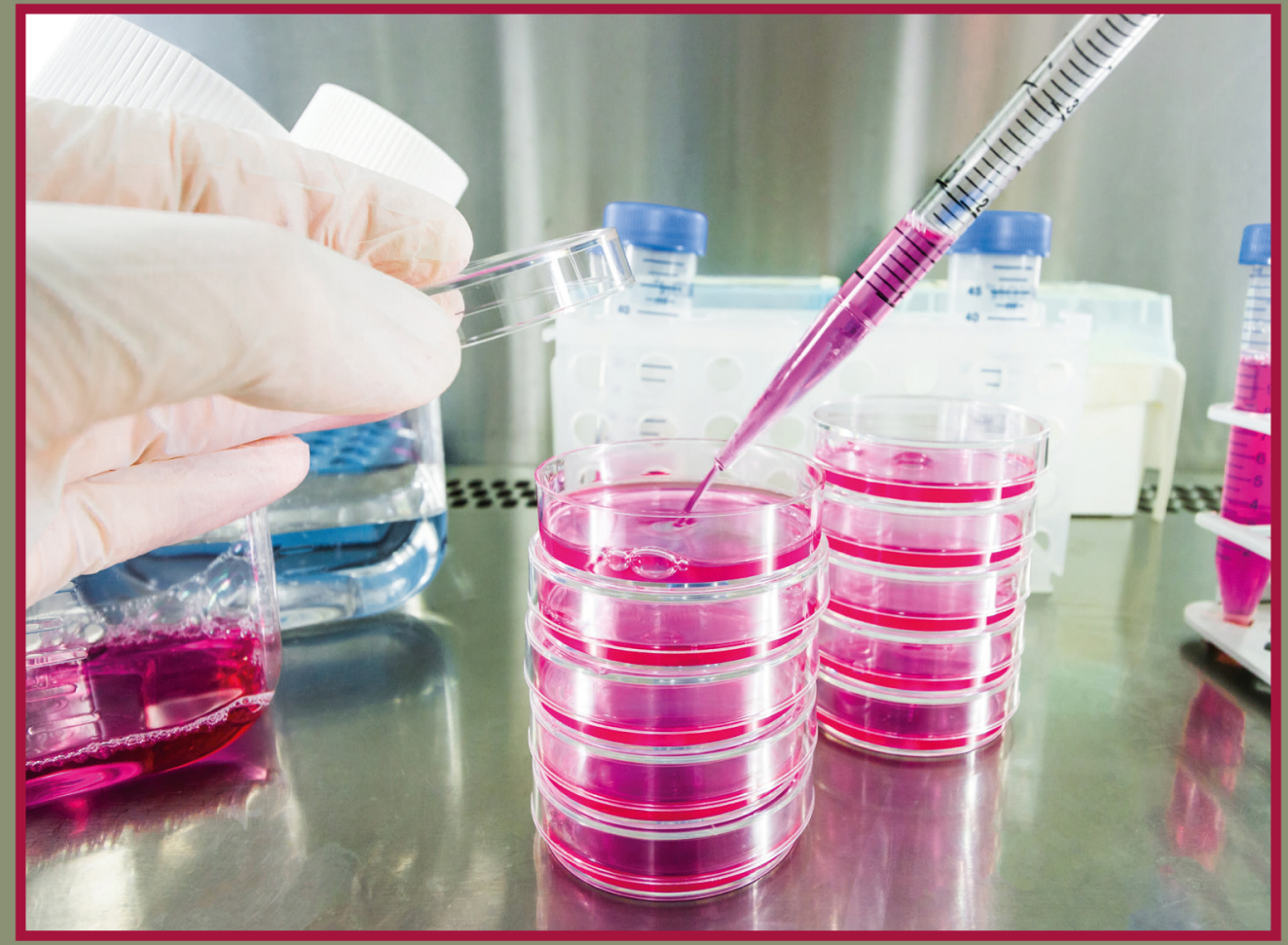

\title{
POLYSACCHARIDE-BASED NANOCOMPOSITES FOR GENE DELIVERY AND TISSUE ENGINEERING
}

Edited by 
Woodhead Publishing Series in Biomaterials

\section{Polysaccharide-Based} Nanocomposites for Gene Delivery and Tissue Engineering

Edited by

Showkat Ahmad Bhawani

Faculty of Resource Science and Technology, Universiti Malaysia Sarawak (UNIMAS), Kota Samarahan, Sarawak, Malaysia

Zoheb Karim

MoRe Research AB, Sweden

Mohammad Jawaid

Biocomposite Technology Laboratory, Institute of Tropical Forestry and Forest Products (INTROP), University Putra Malaysia (UPM), Serdang, Selangor, Malaysia 
Woodhead Publishing is an imprint of Elsevier

The Officers' Mess Business Centre, Royston Road, Duxford, CB22 4QH, United Kingdom

50 Hampshire Street, 5th Floor, Cambridge, MA 02139, United States

The Boulevard, Langford Lane, Kidlington, OX ${ }_{5}{ }_{1 G B}$, United Kingdom

Copyright (C) 2021 Elsevier Inc. All rights reserved.

No part of this publication may be reproduced or transmitted in any form or by any means, electronic or mechanical, including photocopying, recording, or any information storage and retrieval system, without permission in writing from the publisher. Details on how to seek permission, further information about the Publisher's permissions policies and our arrangements with organizations such as the Copyright Clearance Center and the Copyright Licensing Agency, can be found at our website: www.elsevier.com/permissions.

This book and the individual contributions contained in it are protected under copyright by the Publisher (other than as may be noted herein).

\section{Notices}

Knowledge and best practice in this field are constantly changing. As new research and experience broaden our understanding, changes in research methods, professional practices, or medical treatment may become necessary.

Practitioners and researchers must always rely on their own experience and knowledge in evaluating and using any information, methods, compounds, or experiments described herein. In using such information or methods they should be mindful of their own safety and the safety of others, including parties for whom they have a professional responsibility.

To the fullest extent of the law, neither the Publisher nor the authors, contributors, or editors, assume any liability for any injury and/or damage to persons or property as a matter of products liability, negligence or otherwise, or from any use or operation of any methods, products, instructions, or ideas contained in the material herein.

\section{Library of Congress Cataloging-in-Publication Data}

A catalog record for this book is available from the Library of Congress

\section{British Library Cataloguing-in-Publication Data}

A catalogue record for this book is available from the British Library

ISBN: 978-0-12-821230-1

ISBN: 978-0-12-823218-7

For information on all Woodhead publications visit our website at https://www.elsevier.com/books-and-journals

Publisher: Matthew Deans

Acquisitions Editor: Glyn Jones

Editorial Project Manager: Rafael G. Trombaco

Production Project Manager: Vignesh Tamil

Cover Designer: Miles Hitchen 


\section{Section B Polysaccharide based nanocomposites}

for gene delivery

12 Chitosan-based nanocomposites for gene delivery:

Application and future perspectives

Asim Ali Yaqoob, Akil Ahmad, Mohamad Nasir Mohamad Ibrahim, and Mohd Rashid

12.1 Introduction

12.2 Chitosan-A biopolymer $\mathbf{2 4 7}$

12.3 Properties of chitosan $\quad \mathbf{2 4 9}$

12.4 Significance of chitosan nanocomposites $\quad \mathbf{2 5 1}$

12.5 Applications of chitosan nanocomposites $\mathbf{2 5 3}$

12.6 Application in gene delivery $\mathbf{2 5 4}$

12.7 Future perspective and concluding remarks $\quad \mathbf{2 5 6}$

Acknowledgments $\quad 257$

Conflicts of interest $\quad 257$

References $\quad 257$

13 Starch-based nanocomposites for gene delivery 263

Abu Tariq, Showkat Ahmad Bhawani, Mehvish Nisar,

Mohd Razip Asaruddin, and Khalid M. Alotaibi

13.1 Introduction $\quad \mathbf{2 6 3}$

13.2 Starch-based nanocomposites $\mathbf{2 6 6}$

13.3 Applications of starch-based nanocomposites $\quad \mathbf{2 6 9}$

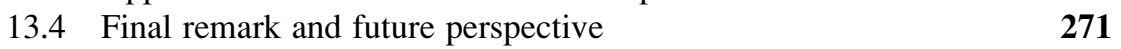

$\begin{array}{ll}\text { References } & \mathbf{2 7 2}\end{array}$

14 Chitosan magnetic nanocomposites for gene delivery 279

Vannessa Lawai and Zainab Ngaini

14.1 Introduction: Gene therapy $\mathbf{2 7 9}$

14.2 Chitosan $\quad 281$

14.3 Magnetic nanocomposite $\mathbf{2 8 3}$

14.4 Chitosan magnetic nanocomposite in gene therapy $\mathbf{2 8 7}$

14.5 Conclusion 290

References $\quad 290$

15 Starch magnetic nanocomposites for gene delivery 295

Mohd Jahir Khan and Zoheb Karim

15.1 Introduction $\quad \mathbf{2 9 5}$

15.2 Starch $\mathbf{2 9 6}$

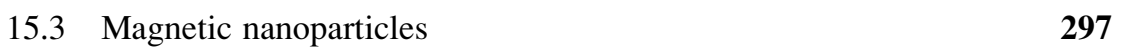

15.4 Surface modification of magnetic nanoparticles $\quad \mathbf{2 9 8}$

15.5 Gene delivery 299 


\section{Chitosan magnetic nanocomposites for gene delivery}

Vannessa Lawai and Zainab Ngaini

Faculty of Resource Science and Technology, Universiti Malaysia Sarawak, Sarawak, Malaysia

\subsection{Introduction: Gene therapy}

Gene therapy is a treatment or prevention of serious disease by repairing, replacing, or regulating the malfunctioning gene using a therapeutic gene by transferring it into a specifically targeted cell nucleus $[1,2]$. Approaches in gene therapy include replacing a mutated gene with a healthy gene, inactivating a malfunctioning gene, and introducing a new gene to assist the treatment of the disease [3]. Nowadays, gene therapy is studied and applied in the treatment of genetic diseases, cancers, acquired immune deficiency syndrome (AIDS), cardiovascular disease [4], and heredopathia [5]. In general, the gene therapy process includes the identification of a mutated or defective gene, followed by cloning of an identical healthy gene called a transgene. The next step is loading the therapeutic gene into a vector that delivers the therapeutic gene into the nucleus. The delivered therapeutic gene is integrated into deoxyribonucleic acid (DNA) followed by the correction of the defective or mutated gene [6].

\subsubsection{Gene delivery systems}

There are three main gene delivery systems: viral vector (e.g., adenovirus, herpes simplex virus, retrovirus, lentivirus, and smallpox virus), nonviral vector (e.g., cationic liposome, a cationic polymer, and nanoparticles), and electroporation [7]. The viral vector method is known to have a high transfection efficiency of $80 \%-90 \%$ due to the ability to enter the cells naturally and express their own protein [3]. There are some limiting factors in using viruses as vectors such as the risk of toxicity, safety, acute inflammatory response, cellular immune response, and integration of nucleic acid sequence into the host genome, which leads to inadequate expression of the gene. Other limitations are the number of genes carried by the virus, high cost of production, unsuitability for large-scale production, insertional mutagenesis, and oncogenic effects in in vivo application [8].

Gene delivery systems via nonviral vectors have low transfection efficiency of $20 \%-30 \%$. However, nonviral vectors have good cell viability of $80 \%-90 \%$, indicating safe transfer of larger DNA molecules [3]. Gene delivery via nonviral vectors 